\title{
POSTAWY WSPÓŁCZESNEJ MŁODZIEŻY AKADEMICKIEJ WZGLEDEM SYTUACJI KRYZYSOWEJ (Z WYKORZYSTANIEM SPRZĘTU RATOWNICZEGO)
}

W artykule została podjęta próba przybliżenia zagrożeń występujących przy uprawianiu żeglugi na morzu. Jednakże ze względu na wielorakość i różnorodność zagadnień opisujących bezpieczeństwo ludzi i objętość artykułu autorzy świadomie zrezygnowali z opisu wielu zagadnień i problemów około towarzyszących.

Trudna sytuacja zazwyczaj pojawia się nieoczekiwanie i wymaga zmiany perspektywy w krótkim czasie. Zmiana ta wpływa na poczucie własnej wartości. Człowiek pozbywa się nadziei oraz złudzeń i wtedy pojawia się wyczerpanie psychiczne i fizyczne. W sytuacji kryzysowej występującej na morzu, gdy zagrożone jest życie i zdrowie człowieka podejmuje się działanie minimalizujące skutki zagrożeń. Na wszystkich statkach pasażerskich prowadzi się $\mathrm{z}$ pasażerami ćwiczebny trening $\mathrm{z}$ użyciem zbiorowych środków ratunkowych. Zgodnie $\mathrm{z}$ konwencją STCW (International Convention on Standards of Training, Certification and Watchkeeping for Seafarers) marynarze przechodzą szkolenie z obsługi środków ratunkowych.

W pierwszej części zostały przedstawione podstawowe akty prawne regulujące badany problem ze szczególnym uwzględnieniem wyposażenia jednostek pływających w sprzęt ratowniczy.

Kolejna część artykułu nie rozpatruje sytuacji destrukcyjnej w wyniku, której rozbitkowie znaleźli się w tratwie ratunkowej. Nie jest tematem opracowania opis katastrofy morskiej,

${ }^{1}$ Dr Hanna Sommer, Katedra Nauk Humanistycznych, Wydział Zarządzania, Politechnika Rzeszowska, Al. Powstańców Warszawy 8, 35-959 Rzeszów, autor korespondencyjny, e-mail: hansom@ prz. edu.pl

Hanna Sommer, PhD, Department of Humanities, Faculty of Management, Rzeszów University of Technology, Al. Powstańców Warszawy 8, 35-959 Rzeszów, corresponding author, e-mail: hansom@prz.edu.pl

${ }^{2}$ Dr Hubert Sommer, Katedra Historii i Teorii Wychowania, Wydział Pedagogiczny, Uniwersytet Rzeszowski, ul. ks. J. Jałowego 24, 35-010 Rzeszów; e-mail: hubsom@wp.pl Hubert Sommer, PhD, Department of History and Upbringing, Faculty of Pedagogy, Rzeszów University, ul. ks. J. Jałowego 24, 35-010 Rzeszów; e-mail: hubsom@wp.pl

${ }^{3}$ Dr inż. Grzegorz Zakrzewski, Akademia Pomorska w Słupsku, Wydział Nauk o Zarządzaniu i Bezpieczeństwie, Instytut Bezpieczeństwa Narodowego, ul. Arciszewskiego 22a, 76-200 Słupsk; e-mail: grzegorz.zakrzewski@apsl.edu.pl

Grzegorz Zakrzewski, PhD, Eng., Pomeranian University in Słupsk, Faculty of Management Science and Security, Department of National University, ul. Arciszewskiego 22a, 76-200 Słupsk; e-mail: grzegorz.zakrzewski@apsl.edu.pl 
a jedynie zachowanie ludzi, w tym szukanie przywódcy wśród ocalałych, przy braku etatowego dowódcy.

Innowacyjnością artykułu jest zastosowanie „racji żywnościowych” będących na wyposażeniu tratwy ratunkowej w katastrofach humanitarnych wśród respondentów i ich ocena.

Słowa kluczowe: katastrofa, rozbitek, środki ratownicze, tratwa ratunkowa, behawior.

Navigare necesse est, vivere non est necesse (Gnaeus Pompeius Magnus, 106-48 p.n.e.)

\section{WPROWADZENIE}

Muszę żeglować, bo to dla mnie konieczne, natomiast zachowanie was przy życiu taką koniecznością już nie jest (wolne tłumaczenie) tak powiedział do załogi, według starożytnego historyka Plutarcha z Cheronei ${ }^{4}$, Pompejusz (w sytuacji dość dramatycznej) zaokrętowywując się jako pierwszy na statek widząc strach, przerażenie i obawę załóg obserwujących trudne warunki hydrometeorologiczne panujące na Morzu Śródziemnym. Statki cumowały i przygotowywały się do wyjścia na morze, w porcie starożytnego Egiptu załadowane zbożem na, które czekały rzymskie legiony. Pompey Magnus miał wiele do stracenia, przede wszystkim politycznie na dostawach frachtu, marynarze-członkowie załóg tylko życie. Dziś rodzi się pytanie czy podzielali nastawienie i determinację swojego dowódcy?

Jak długo sięgnąć w pisaną historię żeglugi można odnieść wrażenie, że załogi statków, okrętów zawsze skazane były tylko na siebie. Na bezkresnym oceanie wszechświatowym trudno było spotkać inną jednostkę pływającą, zatem jedynym środkiem ratowniczym była i jest do dzisiejszego dnia szalupa ratownicza. Czy w minionych czasach była ich wystarczająca ilość, można z całą stanowczością stwierdzić, że nie.

Rewolucją we współczesnym ratownictwie była możliwość wysłania sygnału wzywania pomocy drogą radiową. Guglielmo Marconi ${ }^{5}$ wynalazł i opatentował telegraf bez drutu umożliwiający nadanie sygnału drogą radiową. W 1901 roku sygnał udało się pomyślnie przesłać przez Atlantyk. SOS międzynarodowy sygnał w alfabecie Morsea ${ }^{6}$ składa się z sekwencji trzech powtarzających się bez spacji, ciągów znaków ...---... (trzy „kropki” sygnały krótkie, trzy „kreski” sygnały długie i ponownie trzy „kropki” sygnały krótkie). Po raz pierwszy skutecznie użyto sygnał SOS 10 czerwca 1909 roku w czasie katastrofy brytyjskiego okrętu liniowego Slavonia ${ }^{7}$, który rozbił się na Azorach. Dość ciekawa jest

\footnotetext{
${ }^{4}$ Jeden z największych pisarzy starożytnej Grecji, historyk, filozof-moralista oraz orator, https://pl.wikipedia.org/wiki/Plutarch (dostęp: 31.07.2017 r.).

5 Guglielmo Marconi (ur. 25 kwietnia 1874 r. w Bolonii, Włochy, zm. 20 lipca 1937 r. w Rzymie, Włochy) - włoski fizyk i konstruktor. Jeden z pionierów radia i przemysłu elektronicznego. Laureat Nagrody Nobla z dziedziny fizyki w roku 1909 za wkład w rozwój telegrafii bezprzewodowej. https://pl.wikipedia.org/wiki/Guglielmo_Marconi (dostęp: 31.07.2017 r.).

${ }^{6}$ Kod Morse'a - stworzony w 1838 r. przez Samuela Morse'a i Alfreda Vaila sposób reprezentacji alfabetu, cyfr i znaków specjalnych za pomocą dźwięków, błysków światła, impulsów elektrycznych lub znaków popularnie zwanych kreską i kropką, https://pl.wikipedia.org/wiki/ Kod_Morse\%E2\%80\%99a (dostęp: 31.07.2017 r.).

${ }^{7}$ http://www.polskieradio.pl/39/156/Artykul/861474,Już-ponad-wiek-nadajemy-sygnal-SOS (dostęp: 31.07. 2017 r.).
} 
historia samego międzynarodowego sygnału wzywania pomocy. Na międzynarodowej konferencji poświęconej alfabetowi Morsea w Berlinie dnia 1 lipca 1908 roku sygnał SOS został wprowadzony i zatwierdzony jako sygnał wzywania pomocy.

Dopiero później zaczęto interpretować sygnał SOS jako skrót: „Save Our Souls” „Ocalcie Nasze Dusze”, „Save Our Ship” - „Ocalcie Nasz Statek”, lub „Send Out Succour” - „Wyślijcie Pomoc”. Jedno jest pewne, że sygnał SOS zastąpił wcześniej używany sygnał $\mathrm{CQD}^{8}$ - „,do wszystkich stacji: niebezpieczeństwo”. Dla historycznego porządku należy dodać, że Międzynarodowa Konwencja Radiotelegraficzna w roku 1927 wprowadziła komunikat „mayday” jako uniwersalny sygnał wołania o ratunek. Język angielski jest językiem marynarzy. W dobie wykorzystania sztucznych satelitów Ziemi przekazywanie sygnałów wzywania pomocy zostało doprowadzone do perfekcji. Z uwagi, że ta tematyka nie jest przedmiotem rozważań autorów tego artykułu, uważnych i zaciekawionych tą problematyką czytelników można odesłać do literatury specjalistycznej.

\section{ZASADNICZE AKTY PRAWNE}

Celem głównym artykułu będzie zachowanie się rozbitków w tratwie ratunkowej, dlatego zdecydowano się na szereg uproszczeń, które nie mają wpływu na zasadniczą treść artykułu. Trudno jest przeciętnemu czytelnikowi wychowanemu na lądzie zrozumieć stosowane słownictwo: statek, okręt czy jednostka pływająca. Należy jednak zauważyć, że zaproponowano czytelnikowi bardzo szybki rejs od starożytności do czasów współczesnych. Skróty nie powinny wpłynąć na temat zasadniczych dociekań i badań.

Przechodząc do meritum, przedstawiono dwa zasadnicze dokumenty, które regulują przedmiot dociekań i badań w niniejszym artykule. Nie wgłębiając się w zawiłości prawne, merytoryczne i specjalistyczne przedstawiono stanowisko, jakie przedstawił Dominik Wałkowski - adwokat z Kancelarii Wardyński i Wspólnicy.

„SOLAS -- Międzynarodowa konwencja o bezpieczeństwie życia na morzu, 1974 r., sporządzona w Londynie dnia 1 listopada 1974 r., zmieniona Protokołem sporządzonym w Londynie dnia 17 lutego 1978 r. oraz Protokołem przyjętym w Londynie dnia 11 listopada 1988 r. (Dz.U. z 2016 r., poz. 869) (Konwencja SOLAS) Jednolity tekst przekładu konwencji na język polski został ogłoszony w Dzienniku Ustaw z 2016 r., poz. 869 (warto zapamiętać dane tego Dziennika Ustaw, gdyż czytając sam tytuł ogłoszonego aktu, trudno przypuszczać, że mamy do czynienia z tekstem jednolitym). Tekst ten, oprócz wspomnianych zmian wynikających z ww. protokołów, obejmuje zmiany załącznika do konwencji przyjęte w okresie od 21 kwietnia 1988 r. do 30 listopada 2012 r. i prezentuje stan prawny na 1 stycznia 2014 r.

Obecnie tekst jednolity Konwencji SOLAS nie obejmuje istotnych zmian załącznika do konwencji wynikających z:

- rezolucji Komitetu Bezpieczeństwa na Morzu przyjętych 22 maja 2014 r.: rezolucja MSC.365(93) oraz rezolucja MSC.366(93) oraz

- rezolucji Komitetu Bezpieczeństwa na Morzu przyjętych 21 listopada 2014 r.: rezolucja MSC.380(94) oraz rezolucja MSC.386(94).

\footnotetext{
${ }^{8}$ CQD (wym. si kju di) - dawny sygnał oznaczający zagrożenie na morzu i wzywanie o pomoc. Uznawany jest za pierwszy taki sygnał w komunikacji radiowej, https://pl.wikipedia.org/wiki/CQD (dostęp: 31.07.2017 r.).
} 
Przekład wspomnianych rezolucji został ogłoszony w Dzienniku Ustaw w połowie grudnia 2016 r. (Dz.U. z 2016 r., poz. 2029)"'9.

Z kolejnego dokumentu wybrano tylko te zagadnienia, które będą miały znaczenie dla treści prezentowych $\mathrm{w}$ artykule. Zainteresowanych odsyłamy do literatury przedmiotu i strony z której zaczerpnięto informacje.

„KODEKS LSA - CHARAKTERYSTYKA ŚRODKÓW RATUNKOWYCH Life Saving Appliances Code - Kodeks Urządzeń Ratunkowych - jest kodeksem „należącym” do konwencji SOLAS (Rozdział III, art. 34). Zawarte w nim wymagania dotyczą charakterystyk i zdolności następujących elementów:

- indywidualnych środków ratunkowych - koła ratunkowe, pasy ratunkowe, kombinezony ratunkowe (immersion suit), kombinezony ochronne (anti-exposure suit) oraz środki ochrony cieplnej (thermal protective aid);

- zbiorowych środków ratunkowych - tratwy ratunkowe, łodzie ratunkowe;

- łodzi ratowniczych;

- urządzeń do wodowania - żurawiki, system swobodnego spadku, morskie systemy ewakuacyjne;

- środków sygnalizacji pirotechnicznej - rakiety spadochronowe, pochodnie ręczne, pławki dymne;

- pozostałych urządzeń - wyrzutnia linki ratunkowej, rozgłośnia statkowa.

\section{ZBIOROWE ŚRODKI RATUNKOWE}

Tratwy:

- Zbudowane z materiałów syntetycznych, zapewniających utrzymywanie się na wodzie przez min. $30 \mathrm{dni}$;

- Pływalność zapewniona przez dwie niezależne komory wypornościowe, z których każda z osobna jest w stanie utrzymać tratwę na wodzie obciążoną ludźmi i wyposażeniem;

- Odporne na oddziaływanie temperatur w zakresie $-30^{\circ} \mathrm{C}-+60^{\circ} \mathrm{C}$;

- Wytrzymałe na zrzut do wody z wysokości $18 \mathrm{~m}$;

- Wytrzymałe na skoki na nie z wysokości 4,5 m;

- Zdatne do holowania z prędkością 3 węzłów z pełnym obciążeniem.

Wyposażenie tratwy:

- krążek ratunkowy z linką $30 \mathrm{~m}$;

- nóż i czerpak, 2 gąbki;

- 2 dryfkotwy (jedna zamontowana na stałe);

- 2 pływające, składane wiosła;

- zestaw naprawczy, pompka powietrzna, miarka do wody;

- apteczka pierwszej pomocy;

- otwieracze do puszek;

- wodoszczelna latarka + zapasowe baterie i żarówka;

- lusterko sygnalizacyjne, Gwizdek;

${ }^{9}$ https://prawomorza.pl/ujednolicone-teksty-konwencji-solas-i-marpol-w-dzienniku-ustaw/ (dostęp: 1.08.2017 r.). 
- 6 szt. pochodni ręcznych czerwonych;

- 4 szt. rakiet spadochronowych czerwonych;

- 2 szt. pławek dymnych;

- zestaw do łowienia ryb;

- racje żywnościowe - 10 tys. kJ/osobę;

- pojemniki z wodą pitną po 1,5 litra/osobę;

- tablica sygnałów alarmowych;

- reflektor radarowy;

- tabletki przeciwko chorobie morskiej;

- środki ochrony cieplnej dla 10\% obsady tratwy"10.

Jedną z głównych ról w sposobie organizacji i zapewnienia bezpieczeństwa obok odpowiedniej techniki odgrywa czynnik ludzki. Ważne jest odpowiednie przygotowanie osób, które są odpowiedzialne za nadzorowanie, przestrzegania obowiązujących procedur jak też obsługę czy nadzorowanie wykorzystywanego sprzętu.

\section{METODOLOGICZNE ASPEKTY BADAŃ}

Celem niniejszego artykułu było uzyskanie odpowiedzi od badanych respondentów na temat zachowania się w szeroko rozumianej sytuacji kryzysowej (tutaj na tratwie ratunkowej).

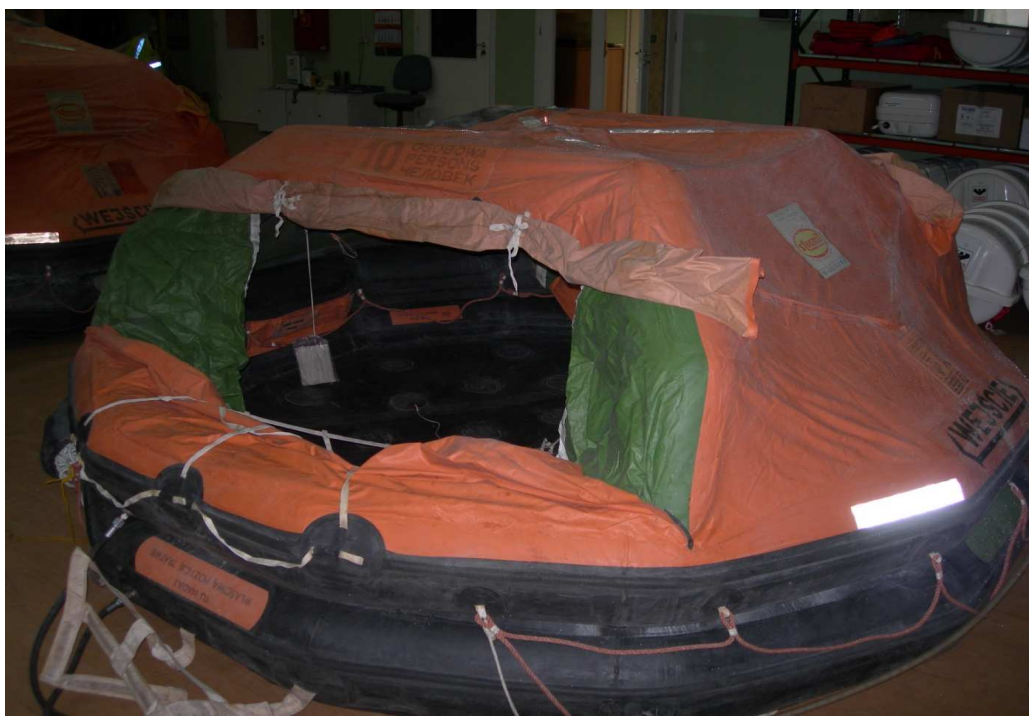

Rys. 1. Zdjęcie rozłożonej tratwy ratunkowej wykonane w serwisie atestacji środków ratunkowych w Gdańsku (dzięki uprzejmości pracowników Sea Light, więcej na stronie: http://www.sealight.pl/) Źródło: zasoby własne autorów.

${ }^{10} \mathrm{http}: / /$ ratownictwo.am.szczecin.pl/index.php/dla-studentow/ratownictwo-morskie/31-kodeks-lsa (dostęp: 1.08.2017 r.). 
W badaniach autorzy wykorzystali kwestionariusz ankietowy. Pytania zawarte w kwestionariuszu i pogłębiona analiza odpowiedzi na nie będą podstawą do sformułowania wniosków. Na podstawie udzielonych odpowiedzi przez potencjalnych rozbitków podjęta została próba zweryfikowania poglądu na satysfakcję po zakończeniu akcji ratowniczej. Pisząc poniży tekst autorzy dokonali wnikliwej analizy literatury przedmiotu oraz publikacji w specjalistycznej prasie. Korzystano również z specjalistycznych materiałów szkoleń i kursów oraz stron internetowych.

Zasadniczym problemem badawczym z którym postanowili zmierzyć się autorzy opracowania, była próba odpowiedzi na następujące pytanie:

Czy współcześni młodzi ludzie reprezentujący dwie największe rzeszowskie uczelnie potrafią dostrzec jakiekolwiek zagrożenia we współczesnym świecie $w$ trzech zasadniczych wymiarach - fizycznym, psychicznym i moralno-duchowym?

Zważywszy, że w niniejszym artykule szczególny nacisk autorzy położyli na zachowanie się badanych w szeroko rozumianej sytuacji kryzysowej (z wykorzystaniem tratwy ratunkowej), stąd też sformułowano tutaj kilka istotnych problemów szczegółowych:

1. Czy badani respondenci są w stanie określić, czym w ogóle są tzw. indywidualne i zbiorowe środki ratownicze?

2. Czy ankietowani studenci są w stanie pokazać/rozpoznać bądź zidentyfikować na jednostce pływającej zbiorowe środki ratunkowe?

3. Czy badani są w stanie przewidzieć swoje zachowanie na tratwie ratunkowej?

4. Jaki jest stopień podporządkowania się respondentów dowódcy tratwy?

5. Czy po zjedzeniu batona energetycznego ankietowani odczuwali uczucie sytości?

6. Czy studenci są w stanie ocenić swój stan emocjonalny w tzw. sytuacji kryzysowej?

7. Jaki sposób zachowania przyjmują respondenci w sytuacji kryzysowej?

Hipotezę zasadniczą jaką przyjęli autorzy sprowadzono do stwierdzenia, iż: Niezależnie od tego czy mamy do czynienia z obszarem fizycznym, psychicznym czy moralno-duchowym badani studenci zdecydowanie stoją na stanowisku, iż jakiekolwiek zagrożenia w obecnej rzeczywistości są raczej mało prawdopodobne.

Z kolei hipotezy szczegółowe wyglądają następująco:

1. Płeć jest zmienną wyraźnie różnicującą odpowiedzi badanych i tak ankietowani studenci częściej wybierają odpowiedź twierdzącą w przypadku trafnego zdefiniowania indywidualnych i zbiorowych środków ratowniczych aniżeli ma to miejsce w przypadku studentek.

2. Niezależnie od miejsca zamieszkania badani studenci mają wyraźny problem z odpowiedzią na pytanie dotyczące rozpoznania oraz identyfikacji czy dotarcia do zbiorowych środków ratunkowych na tratwie.

3. Założono, że typ uczelni nie ma większego przełożenia na rezultat badawczy dotyczący przewidywalności zachowania respondentów na tratwie ratunkowej - większość z nich nie będzie potrafiła właściwie zantycypować swojej postawy.

4. Badani studenci niezależnie od deklarowanej wiary religijnej w ekstremalnej sytuacji zagrażającej ich życiu potrafią podporządkować się dowódcy tratwy.

5. Proponowany przez autorów badania baton energetyczny niezależnie od deklarowanej aktywności fizycznej studentów spełniał swoją rolę - po jego zjedzeniu, respondenci czuli częściowe bądź też całkowite uczucie sytości.

6. Umiejętności pływackie istotnie wpływają na stan emocjonalny w sytuacji kryzysowej, im są one wyższe, tym mniejszy jest strach (lęk) przed ewentualnym niebezpiecznym zdarzeniem w życiu (tutaj na wodzie). 
7. Niezależnie od doświadczenia traumatycznych zdarzeń badanych w ich dotychczasowym życiu, deklarują oni w większości przypadków zdecydowane lub umiarkowane działanie w sytuacji kryzysowej.

Badaniami objęto studentów dwóch największych uczelni Rzeszowa, a mianowicie politechniki i uniwersytetu. Ankietowani legitymowali się ponadto różną płcią, miejscem zamieszkania, a także deklarowaną wiarą religijną. Badania przeprowadzono w Rzeszowie na przełomie maja i czerwca 2017 roku. W tabeli 1 zamieszczono szczegółową charakterystykę badanej populacji.

Tabela 1. Charakterystyka badanej populacji dla $\mathrm{n}=85=100 \%$

\begin{tabular}{|c|c|c|}
\hline \multicolumn{2}{|r|}{ Kategorie odpowiedzi } & $\%$ \\
\hline \multirow{2}{*}{ Płeć } & Kobiety dla $n=60=100 \%$ & $70,1 \%$ \\
\hline & Mężczyźni dla $\mathrm{n}=25=100 \%$ & $29,9 \%$ \\
\hline \multirow{3}{*}{ Miejsce zamieszkania } & Wieś dla $\mathrm{n}=48=100 \%$ & $56,4 \%$ \\
\hline & Miasto do 100 tys. dla $n=16=100 \%$ & $18,8 \%$ \\
\hline & Miasto od 100 do 250 tys. dla $n=21=100 \%$ & $24,8 \%$ \\
\hline \multirow{2}{*}{ Uczelnia } & Politechnika dla $\mathrm{n}=66=100 \%$ & $77,6 \%$ \\
\hline & Uniwersytet dla $\mathrm{n}=19=100 \%$ & $22,4 \%$ \\
\hline \multirow{2}{*}{ Autodeklaracja religijna } & Wierzący dla $\mathrm{n}=80=100 \%$ & $94,1 \%$ \\
\hline & Niewierzący dla $\mathrm{n}=5=100 \%$ & $5,9 \%$ \\
\hline \multirow{4}{*}{ Aktywność fizyczna } & Regularnie uprawiający sport dla $\mathrm{n}=27=100 \%$ & $31,8 \%$ \\
\hline & Nieregularnie uprawiający sport dla $n=26=100 \%$ & $30,2 \%$ \\
\hline & Sporadycznie uprawiający sport dla $\mathrm{n}=25=100 \%$ & $29,6 \%$ \\
\hline & $\begin{array}{l}\text { Nie podejmujący żadnej aktywności fizycznej } \\
\text { dla } n=7=100 \%\end{array}$ & $8,4 \%$ \\
\hline \multirow{2}{*}{$\begin{array}{l}\text { Uprawianie sportów } \\
\text { wodnych }\end{array}$} & Tak dla $\mathrm{n}=11=100 \%$ & $12,9 \%$ \\
\hline & Nie dla $n=74=100 \%$ & $87,1 \%$ \\
\hline \multirow{2}{*}{ Umiejętność pływania } & Tak dla $n=56=100 \%$ & $65,9 \%$ \\
\hline & Nie dla $n=29=100 \%$ & $34,1 \%$ \\
\hline \multirow{2}{*}{$\begin{array}{c}\text { Doświadczenie jakichkol- } \\
\text { wiek sytuacji kryzysowych } \\
\text { w życiu badanych }\end{array}$} & Tak dla $\mathrm{n}=49=100 \%$ & $57,6 \%$ \\
\hline & Nie dla $n=36=100 \%$ & $42,4 \%$ \\
\hline
\end{tabular}

Źródło: badania własne.

W badanej populacji wzięło udział 60 kobiet i 25 mężczyzn, co stanowiło odpowiednio $70,1 \%$ i $29,9 \%$. Warto nadmienić, iż ankietowani respondenci reprezentowali dwie największe rzeszowski uczelnie - Politechnikę $(77,6 \%)$ oraz Uniwersytet $(22,4 \%)$. Największą grupę badawczą stanowili studenci legitymujący się pochodzeniem wiejskim (ponad 56\%), najmniejszą ci, którzy na stałe zamieszkują w miastach średniej wielkości - do 100 tysięcy mieszkańców (niecałe 19\%). Zdecydowana większość młodzieży akademickiej autodeklaruje się jako wierząca - ponad $94 \%$ badanych. Z aktywnością fizyczną respondentów nie jest najgorzej, bowiem ponad $60 \%$ regularnie, bądź nieregularnie uprawia sport. Wśród badanych zaledwie 8,4\% nie przejawia żadnej aktywności fizycznej. Zdecydowanie gorzej wygląda uprawianie szeroko rozumianych sportów wodnych, i tak absolutna większość stu- 
dentów (ponad 87\%) nie miała z tym nigdy do czynienia. Na szczęście umiejętności pływackie posiada blisko $66 \%$, a to już jest zjawiskiem godnym pochwały. W kwestionariuszu ankiety autorzy spytali również młodych ludzi o doświadczenie w życiu tzw. sytuacji kryzysowych (przykładowo śmierć kogoś bliskiego, ciężka choroba itp.). W wyniku zebranego materiału badawczego okazało się, że ponad 57\% badanych przeżyła w swoim życiu sytuacje traumatyczne, które miały wpływ na kształtowanie ich osobowości.

Analiza danych metryczkowych wskazuje jednoznacznie, iż ankietowani stanowili zróżnicowaną grupę badawczą ze względu na umieszczone w niej zmienne.

Jedna z pierwszych kwestii empirycznych, którą autorzy poddali analizie było uzyskanie odpowiedzi na to, czy badani wiedzą czym są indywidualne, a czym zbiorowe środki ratownicze. Uzyskane odpowiedzi skorelowano z płcią ankietowanych studentów.

Tabela 2. Wiedza badanych na temat indywidualnych i zbiorowych środków ratowniczych a ich płeć dla $\mathrm{n}=85=100 \%$

\begin{tabular}{|l|c|c|c|c|c|c|}
\hline \multirow{2}{*}{$\begin{array}{c}\text { Czy wie Pani/Pan co } \\
\text { to są indywidualne } \\
\text { i zbiorowe środki } \\
\text { ratownicze? }\end{array}$} & \multicolumn{2}{|c|}{$\begin{array}{c}\text { Kobiety dla } \\
\mathrm{n}=60=100 \%\end{array}$} & \multicolumn{2}{c|}{$\begin{array}{c}\text { Mężczyźni dla } \\
\mathrm{n}=25=100 \%\end{array}$} & \multicolumn{2}{c|}{$\begin{array}{c}\text { Ogółem dla } \\
\mathrm{n}=85=100 \%\end{array}$} \\
\cline { 2 - 7 } & $\mathrm{n}$ & $\%$ & $\mathrm{n}$ & $\%$ & $\mathrm{n}$ & $\%$ \\
\hline Tak & 18 & 30 & 15 & 60 & 33 & 38,8 \\
\hline Nie & 42 & 70 & 10 & 40 & 52 & 61,2 \\
\hline
\end{tabular}

Źródło: badania własne.

Uzyskane wyniki wskazuję, iż blisko $40 \%$ ogółu badanych jest w stanie powiedzieć czym są tzw. indywidualne i zbiorowe środki ratownicze (najczęściej spotykane odpowiedzi to odpowiednio: koła ratunkowe, tratwy bądź pontony). Godne odnotowania ze statystycznego punktu widzenia jest jednak to, że znacznie lepiej radzą sobie z odpowiedzią na zadane pytanie badani studenci, aniżeli studentki (odpowiednio: 60\% i 30\%). Może to świadczyć o tym, że są oni zdecydowanie bardziej zainteresowani analizowaną tematyką, ze względów czysto formalnych i technicznych. To mężczyźni przecież częściej mają zapewnić bezpieczny byt rodzinie, aniżeli kobiety. Chociaż w XXI wieku ta kwestia nie wydaje się już tak oczywista.

Dramatycznie wygląda kolejna kwestia poddana przez autorów badaniom, a mianowicie opinia respondentów na temat tego, czy są w stanie na jednostce pływającej nie tylko pokazać/rozpoznać czy zidentyfikować, ale również dotrzeć do zbiorowych środków ratunkowych. Punktem odniesienia stało się tutaj skorelowanie pytania z miejscem zamieszkania badanych.

Wyniki zawarte w tabeli wskazują dość jednoznacznie, iż większość badanych studentów nie potrafiła na sformułowane w kwestionariuszu ankiety pytanie odpowiedzieć (blisko $66 \%$ ogółu respondentów). Ze statystycznego punktu widzenia godne odnotowania jest również to, iż ci respondenci, którzy poradziliby sobie w takiej sytuacji kryzysowej legitymują się pochodzeniem wielkomiejskim (ponad 28\%). Zarówno ankietowani pochodzący ze wsi, jak i z tak zwanych miast średniej wielkości nie potrafiliby w takiej sytuacji prawidłowo zareagować (odpowiednio: 22,9\% i 31,2\%). 
Tabela 3. Umiejętność pokazania, rozpoznania, identyfikacji oraz dotarcia do zbiorowych środków ratowniczych a miejsce zamieszkania dla $\mathrm{n}=85=100 \%$

\begin{tabular}{|c|c|c|c|c|c|c|c|c|}
\hline \multirow{3}{*}{$\begin{array}{c}\text { Czy jest Pani/Pan w stanie, } \\
\text { na jednostce pływającej, poka- } \\
\text { zać/rozpoznać/zidentyfikować } \\
\text { w dalszej kolejności dotrzeć } \\
\text { do zbiorowych środków } \\
\text { ratunkowych? }\end{array}$} & \multicolumn{8}{|c|}{ Miejsce zamieszkania } \\
\hline & \multicolumn{2}{|c|}{$\begin{array}{c}\text { Wieś dla } \\
\mathrm{n}=48=100 \%\end{array}$} & \multicolumn{2}{|c|}{$\begin{array}{c}\text { Miasto do } \\
100 \text { tys. dla } \\
\mathrm{n}=16=100 \%\end{array}$} & \multicolumn{2}{|c|}{$\begin{array}{l}\text { Miasto od } 100 \\
\text { do } 250 \text { tys. dla } \\
n=21=100 \%\end{array}$} & \multicolumn{2}{|c|}{$\begin{array}{c}\text { Ogółem dla } \\
n=85=100 \%\end{array}$} \\
\hline & $\mathrm{n}$ & $\%$ & $\mathrm{~N}$ & $\%$ & $\mathrm{n}$ & $\%$ & $\mathrm{~N}$ & $\%$ \\
\hline Tak & - & - & - & - & 6 & 28,6 & 6 & 7,1 \\
\hline $\mathrm{Nie}$ & 11 & 22,9 & 5 & 31,2 & 7 & 33,3 & 23 & 27,1 \\
\hline Trudno powiedzieć & 37 & 77,1 & 11 & 68,8 & 8 & 38,1 & 56 & 65,8 \\
\hline
\end{tabular}

Źródło: badania własne.

Uzyskane rezultaty można uznać za bardzo niepokojące, bowiem hipotetycznie dramatyczna sytuacja na morzu może mieć opłakane skutki w momencie gdy okaże się, że większość pasażerów nie ma pojęcia, co w takiej sytuacji zrobić. Wniosek wydaje się nazbyt oczywisty - niezbędne wydają się tutaj odpowiednie szkolenia i kursy, które przygotują potencjalnych rozbitków do tego, jak w takiej sytuacji zareagować.

Kolejną kwestią poddaną analizie był rysunek przedstawiający tratwę ratunkową. Pytanie było oczywiste - co ów rysunek przedstawia i gdzie Pani/Pan się z nim zetknęła/zetknął?

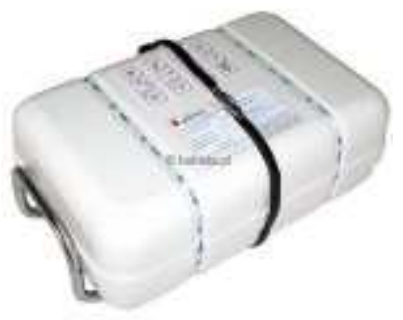

Rys. 2. Złożona tratwa ratunkowa

Źródło: zasoby własne autorów

W przypadku tego pytania wyniki można uznać za zadowalające, bowiem dla ponad $74 \%$ ogółu badanych na rysunku znajduje się tratwa ratunkowa, co oczywiście jest zgodne z prawdą. Dla blisko $26 \%$ ankietowanych jest to coś innego - najczęściej udzielaną odpowiedzią była walizka ewentualnie namiot. Jak wspomniano powyżej uzyskane wyniki mogą napawać optymizmem, zwłaszcza, że studenci na ów temat wiedzę zaczerpnęli nie tylko z Internetu, ale nierzadko z zajęć na macierzystych uczelniach.

Kolejna kwestia, którą poddano analizie to przewidywalność zachowania respondentów na tratwie ratunkowej. W tym wypadku analizowane odpowiedzi autorzy skorelowali z uczelnią na której studiują respondenci. 
Tabela 4. Przewidywalność zachowań na tratwie ratunkowej, a typ uczelni dla $n=85=100 \%$

\begin{tabular}{|l|c|c|c|c|c|c|}
\hline \multirow{2}{*}{$\begin{array}{c}\text { Czy potrafi Pani/Pan } \\
\text { przewidzieć swoje za- } \\
\text { chowanie na tratwi } \\
\text { ratunkowej? }\end{array}$} & \multicolumn{2}{|c|}{$\begin{array}{c}\text { Politechnika dla } \\
\mathrm{n}=66=100 \%\end{array}$} & \multicolumn{2}{c|}{$\begin{array}{c}\text { Uniwersytet dla } \\
\mathrm{n}=19=100 \%\end{array}$} & \multicolumn{2}{c|}{$\begin{array}{c}\text { Ogółem dla } \\
\mathrm{n}=85=100 \%\end{array}$} \\
\cline { 2 - 7 } & $\mathrm{N}$ & $\%$ & $\mathrm{n}$ & $\%$ & $\mathrm{n}$ & $\%$ \\
\hline Tak & 11 & 16,6 & - & - & 11 & 12,8 \\
\hline Nie & 16 & 24,2 & 4 & 21,1 & 20 & 23,6 \\
\hline Trudno powiedzieć & 39 & 59,2 & 15 & 78,9 & 54 & 63,6 \\
\hline
\end{tabular}

Źródło: badania własne.

Ekstremalne sytuacje bardzo często są przyczyną nieprzewidywalnych zachowań. Stąd też pytanie autorów o ten aspekt. Uzyskane rezultaty były nietrudne do przewidzenia, chociaż nie do końca. Okazało się bowiem, iż prawie $64 \%$ ogółu respondentów nie potrafiło zająć w analizowanej kwestii stanowiska. Częściej czynili to studenci uniwersytetu (odpowiednio: $78,9 \%$ i 59,2\%). Tu jednak należałoby odnotować, iż 16,6\% badanych studentów na co dzień studiujących na politechnice doskonale zna siebie i wie, jak zachować się w tzw. trudnej sytuacji. Studentów uniwersytetu w tym wypadku autorzy nie odnotowali. Może to świadczyć o tym, iż zupełnie inna jest specyfika studiów na uczelni technicznej, a znacząco inna na takiej, w której dominują kierunki humanistyczne. Stąd też przyszli inżynierowie łatwiej asymilują tzw. niebezpieczne zdarzenia i sytuacje o podłożu kryzysowym, aniżeli czynią to przyszli poloniści, socjolodzy, medycy czy pedagodzy.

Podporządkowanie się dowódcy tratwy było kolejnym aspektem, który przebadali autorzy niniejszego opracowania. Zastosowano tutaj popularne skalowanie, gdzie 1 - oznaczało brak podporządkowania, a 5 - całkowite podporządkowanie. Uzyskane wyniki skorelowano z autodeklaracjami religijnymi badanych.

Tabela 5. Stopień podporządkowania dowódcy tratwy a autodeklaracja religijna badanych dla $\mathrm{n}=85=100 \%$

\begin{tabular}{|l|c|c|c|c|c|c|}
\hline \multirow{2}{*}{$\begin{array}{c}\text { Proszę ocenić swój stopień } \\
\text { podporządkowania się } \\
\text { dowódcy tratwy? W skali } \\
\text { od 1-5 (1 - brak podporząd- } \\
\text { kowania; 5 - całkowite } \\
\text { podporządkowanie) }\end{array}$} & \multicolumn{2}{|c|}{$\begin{array}{c}\text { Wierzący dla } \\
\mathrm{n}=80=100 \%\end{array}$} & \multicolumn{2}{|c|}{$\begin{array}{c}\text { Niewierzący dla } \\
\mathrm{n}=5=100 \%\end{array}$} & \multicolumn{2}{|c|}{$\begin{array}{c}\text { Ogółem dla } \\
\mathrm{n}=85=100 \%\end{array}$} \\
\cline { 2 - 8 } & $\mathrm{N}$ & $\%$ & $\mathrm{n}$ & $\%$ & $\mathrm{n}$ & $\%$ \\
\hline $\begin{array}{l}1-\text { całkowity brak } \\
\text { podporządkowania }\end{array}$ & - & - & - & - & - & - \\
\hline $\begin{array}{l}2-\text { czę́siowy brak } \\
\text { podporządkowania }\end{array}$ & - & - & 1 & 20 & 1 & 1,2 \\
\hline $3-$ postawa neutralna & 29 & 36,3 & - & - & 29 & 34,1 \\
\hline $\begin{array}{l}4-\text { częściowe } \\
\text { podporządkowanie }\end{array}$ & 19 & 23,7 & 4 & 80 & 23 & 27,1 \\
\hline $\begin{array}{l}5-\text { całkowite } \\
\text { podporządkowanie }\end{array}$ & 32 & 40 & - & - & 32 & 37,6 \\
\hline
\end{tabular}

Źródło: badania własne. 
Wyniki zdaja się być dość interesujące. Okazało się bowiem, iż deklarowana przez respondentów wiara religijna ma znaczenie w analizowanej kwestii. Wśród wierzących aż $40 \%$ zdecydowanie stoi na stanowisku, iż podporządkowanie się dowódcy na tratwie jest absolutną koniecznością. Wśród ankietowanych, którzy deklarują ateizm, tak odpowiadających nie odnotowano. Biorąc pod uwagę ogół przebadanych studentów warto odnotować, że ponad $34 \%$ z nich w takiej sytuacji zachowuje się neutralnie, co oczywiście może budzić pewien niepokój. Całkowity brak podporządkowania dowódcy został przez młodych ludzi zupełnie zignorowany, co z kolei ma pozytywny wydźwięk.

Badanym przez autorów respondentom zaserwowano tzw. baton energetyczny, który ma za zadanie w sytuacji kryzysowej pomóc przetrwać aż do przybycia pomocy. Uzyskane rezultaty przedstawiono w tabeli 6 .

Tabela 6. Uczucie sytości po spożyciu batonu energetycznego a aktywność fizyczna badanych dla $\mathrm{n}=85=100 \%$

\begin{tabular}{|c|c|c|c|c|c|c|c|c|c|c|}
\hline \multirow{3}{*}{$\begin{array}{c}\text { Czy ma Pani/Pan } \\
\text { uczucie sytości po } \\
\text { konsumpcji batona } \\
\text { energetycznego? } \\
\text { Oceń w skali od } \\
1-5 \text { ( } 1 \text { - brak } \\
\text { uczucia sytości; } \\
5 \text { - bardzo duże } \\
\text { uczucie sytości) }\end{array}$} & \multicolumn{10}{|c|}{ Aktywność fizyczna } \\
\hline & \multicolumn{2}{|c|}{$\begin{array}{c}\text { Uprawiający } \\
\text { sport } \\
\text { regularnie dla } \\
\mathrm{n}=27=100 \%\end{array}$} & \multicolumn{2}{|c|}{$\begin{array}{c}\text { Uprawiający } \\
\text { sport nieregu- } \\
\text { larnie dla } \\
\mathrm{n}=26=100 \%\end{array}$} & \multicolumn{2}{|c|}{$\begin{array}{c}\text { Uprawiający } \\
\text { sport spora- } \\
\text { dycznie dla } \\
\mathrm{n}=25=100 \%\end{array}$} & \multicolumn{2}{|c|}{$\begin{array}{l}\text { Nie podejmu- } \\
\text { jący żadnej } \\
\text { aktywności } \\
\text { fizycznej dla } \\
\mathrm{n}=7=100 \%\end{array}$} & \multicolumn{2}{|c|}{$\begin{array}{c}\text { Ogółem dla } \\
\mathrm{n}=85= \\
100 \%\end{array}$} \\
\hline & $\mathrm{n}$ & $\%$ & $\mathrm{n}$ & $\%$ & $\mathrm{n}$ & $\%$ & $\mathrm{n}$ & $\%$ & $\mathrm{~N}$ & $\%$ \\
\hline $\begin{array}{l}1-\text { całkowity } \\
\text { brak uczucia } \\
\text { sytości }\end{array}$ & - & - & - & - & 4 & 16 & 1 & 14,3 & 5 & 5,9 \\
\hline $\begin{array}{l}2 \text { - częściowy } \\
\text { brak uczucia } \\
\text { sytości }\end{array}$ & 3 & 11,1 & 4 & 15,4 & 3 & 12 & 2 & 28,6 & 12 & 14,1 \\
\hline $\begin{array}{l}3 \text { - postawa } \\
\text { neutralna }\end{array}$ & 6 & 22,2 & 7 & 26,9 & 5 & 20 & 4 & 57,1 & 22 & 25,9 \\
\hline $\begin{array}{l}\text { - częściowe } \\
\text { (niepełne) } \\
\text { uczucie sytości }\end{array}$ & 8 & 29,6 & 7 & 26,9 & 6 & 24 & - & - & 21 & 24,7 \\
\hline $\begin{array}{l}5 \text { - całkowite } \\
\text { (pełne) uczucie } \\
\text { sytości }\end{array}$ & 10 & 37,1 & 8 & 30,8 & 7 & 28 & - & - & 25 & 29,4 \\
\hline
\end{tabular}

Źródło: badania własne.

Uzyskane wyniki wskazują na to, iż blisko $30 \%$ ogółu przebadanych respondentów po zjedzeniu tzw. batona energetycznego czuła się najedzona. W ich opinii byłby on w stanie zrekompensować im w sytuacji kryzysowej całodzienne pożywienie. Znamienny jest jednak tutaj inny fakt, a mianowicie najmocniej odpowiedź taką akcentowali respondenci, którzy na co dzień regularnie uprawiają sport (ponad 37\%) i ci, którzy go uprawiają z mniejszą częstotliwością (niecałe $31 \%$ badanych). Postawę neutralną względem pożywności i energetyczności batona najmocniej manifestowali respondenci, którzy nie podejmują żadnej 
aktywności związanej ze sportem (ponad 57\% ankietowanych). Ponadto, niemały był odsetek respondentów wśród sporadycznie uprawiających sport, którzy w ogóle nie najedli się przedłożonym do badań batonem (16\%), rys. 3 .

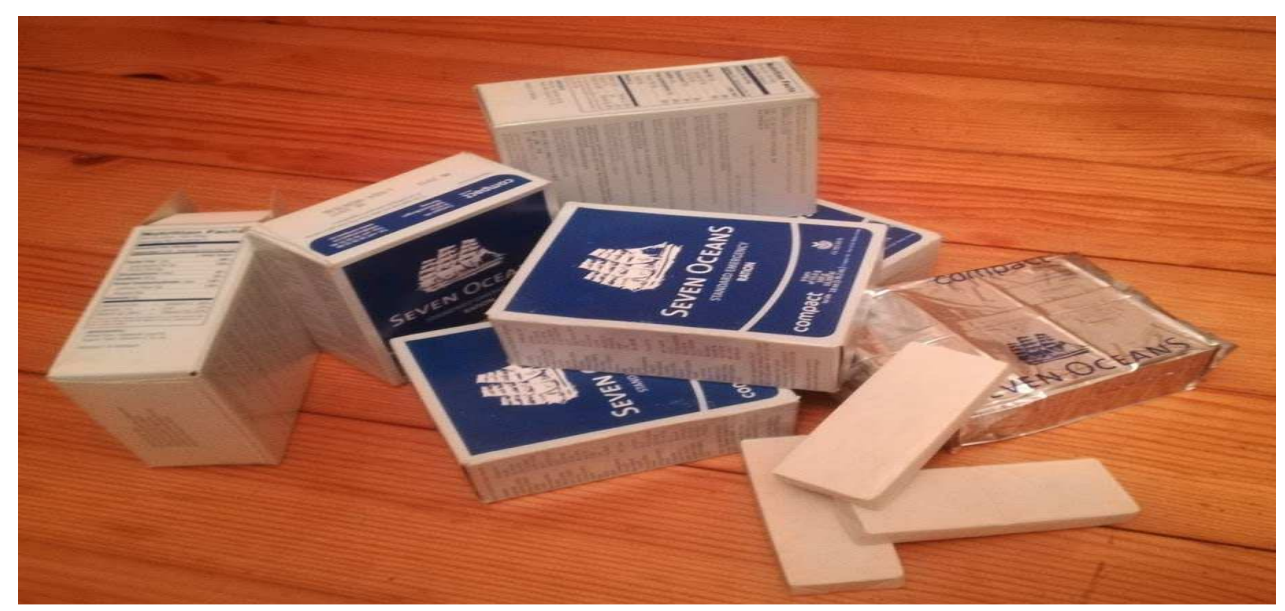

Rys. 3. Batony energetyczne, które mają pomóc przetrwać w sytuacji kryzysowej (dzięki uprzejmości pracowników Sea Light, więcej na stronie: http://www.sealight.pl/)

Źródło: zbiory własne autorów.

Dokonując krótkiego podsumowania autorzy stwierdzają, iż walory energetyczne batona wydają się być niepodważalne, niemniej jednak wśród studentów panowała dość powszechna opinia, że smak tegoż batona pozostawia wiele do życzenia (jak stwierdziła znacząca ich grupa, jest on zwyczajnie zbyt mdły i pozbawiony jakiegokolwiek smaku).

Autorzy opracowania spytali również biorących w badaniach respondentów o to, by spróbowali określić swój stan emocjonalny w sytuacji, która niesie za sobą oznaki ewentualnego kryzysu. Odpowiedzi skorelowano z umiejętnościami pływackimi ankietowanych.

Wyniki aż nazbyt czytelnie wskazują, iż tak ważna cecha jak umiejętność pływania wpływa zasadniczo na reakcję badanych w sytuacji kryzysowej. I tak, ponad $46 \%$ respondentów umiejących pływać bez specjalnego strachu czy lęku umiałaby właściwie zareagować na nieprzewidywalne, a przy tym niebezpieczne zdarzenie. Dla porównania, respondentów, którzy pływać nie potrafią, a zareagowaliby bez specjalnych emocji było nieco ponad $10 \%$. Wniosek wydaje się być oczywisty - dobra umiejętność pływania w sposób zasadniczy wpływa na reagowanie w sytuacjach trudnych (za przykład może posłużyć tonięcie łodzi, statku czy okrętu). Warto odnotować, iż w grupie niepływających ponad 54\% stanowią ci, u których występuje częściowe lub całkowite natężenie emocji połączone $\mathrm{z}$ gniewem czy wręcz wrogością w momencie kryzysu. Uzyskany rezultat jedynie potwierdza założoną przez autorów powyżej tezę. Można przyjąć, iż sportowy tryb życia sprzyja skuteczniejszej reakcji na analizowane w tym opracowaniu sytuacje kryzysowe. 
Tabela 7. Stan emocjonalny badanych w sytuacji kryzysowej a umiejętności pływackie badanych dla $\mathrm{n}=85=100 \%$

\begin{tabular}{|c|c|c|c|c|c|c|}
\hline \multirow{3}{*}{$\begin{array}{c}\text { Proszę nazwać swój } \\
\text { aktualny stan emocjo- } \\
\text { nalny w sytuacji kryzyso- } \\
\text { wej (wymiar afektywny) }\end{array}$} & \multicolumn{6}{|c|}{ Umiejętności pływackie } \\
\hline & \multicolumn{2}{|c|}{$\begin{array}{c}\text { Tak } \\
\text { dla } n=56=100 \%\end{array}$} & \multicolumn{2}{|c|}{$\begin{array}{c}\text { Nie } \\
\text { dla } n=29=100 \%\end{array}$} & \multicolumn{2}{|c|}{$\begin{array}{c}\text { Ogółem } \\
\text { dla } \mathrm{n}=85=100 \%\end{array}$} \\
\hline & $\mathrm{n}$ & $\%$ & $\mathrm{n}$ & $\%$ & $\mathrm{n}$ & $\%$ \\
\hline $\begin{array}{l}1 \text { - całkowity brak } \\
\text { widocznych emocji } \\
\text { (strachu/leku) }\end{array}$ & 26 & 46,4 & 3 & 10,3 & 29 & 34,2 \\
\hline $\begin{array}{l}2 \text { - częściowy brak } \\
\text { widocznych emocji } \\
\text { (strachu/lęku) }\end{array}$ & 13 & 23,2 & 6 & 20,7 & 19 & 22,3 \\
\hline $\begin{array}{l}3 \text { - postawa neutralna } \\
\text { (smutek/melancholia) }\end{array}$ & 6 & 10,7 & 4 & 13,8 & 10 & 11,8 \\
\hline $\begin{array}{l}4 \text { - częściowe natężenie } \\
\text { emocji (gniewu/wrogości) }\end{array}$ & 8 & 14,3 & 7 & 24,1 & 15 & 17,6 \\
\hline $\begin{array}{l}5 \text { - całkowite natężenie } \\
\text { emocji (gniewu/wrogości) }\end{array}$ & 3 & 5,4 & 9 & 31,1 & 12 & 14,1 \\
\hline
\end{tabular}

Źródło: badania własne.

W kolejnym pytaniu autorzy skupili się na uzyskaniu odpowiedzi od badanych na temat sposobów zachowania respondentów w sytuacji kryzysowej. Skorelowano to z doświadczeniem studentów w życiu jakiejkolwiek trudnej sytuacji życiowej (tab. 8).

Tabela 8. Sposób zachowania badanych w sytuacji kryzysowej a doświadczenie przez nich w życiu jakiegokolwiek traumatycznego zdarzenia dla $\mathrm{n}=85=100 \%$

\begin{tabular}{|l|c|c|c|c|c|c|}
\hline \multirow{2}{*}{$\begin{array}{c}\text { Proszę określić swój } \\
\text { sposób zachowania } \\
\begin{array}{c}\text { w sytuacji kryzysowej } \\
\text { (wymiar } \\
\text { behawioralny) }\end{array}\end{array}$} & \multicolumn{5}{|c|}{$\begin{array}{c}\text { Tak dla } \\
\text { beświadczenie sytuacji kryzysowych w życiu }\end{array}$} \\
\cline { 2 - 7 } & $\mathrm{n}=49=100 \%$ & \multicolumn{2}{|c|}{$\begin{array}{c}\text { Nie dla } \\
\mathrm{n}=36=100 \%\end{array}$} & \multicolumn{2}{c|}{$\begin{array}{c}\text { Ogółem dla } \\
\mathrm{n}=85=100 \%\end{array}$} \\
\hline $\begin{array}{l}1-\text { zdecydowane } \\
\text { działanie }\end{array}$ & 19 & 38,8 & 7 & 19,4 & 26 & 30,6 \\
\hline $\begin{array}{l}2-\text { umiarkowane } \\
\text { działanie }\end{array}$ & 15 & 30,1 & 8 & 22,3 & 23 & 27,1 \\
\hline $\begin{array}{l}3-\text { postawa neutralna } \\
\text { unikanie) }\end{array}$ & 3 & 6,1 & 5 & 13,9 & 8 & 9,4 \\
\hline $\begin{array}{l}4-\text { raczej brak } \\
\text { działania }\end{array}$ & 7 & 14,8 & 9 & 25 & 16 & 18,8 \\
\hline $\begin{array}{l}5-\text { zdecydowany brak } \\
\text { działania (paraliż } \\
\text { działania) }\end{array}$ & 5 & 10,2 & 7 & 19,4 & 12 & 14,1 \\
\hline
\end{tabular}

Źródło: badania własne. 
Analizując uzyskane rezultaty badań możemy dostrzec istotną prawidłowość, a mianowicie, blisko $60 \%$ ogółu ankietowanych studentów w sytuacji kryzysowej potrafiłoby zdecydowanie lub w sposób umiarkowany zacząć skutecznie przeciwdziałać, zdając sobie sprawę z czyhającego niebezpieczeństwa. Tu jednak należy odnotować, iż mocniej akcentują to respondenci, którzy w swoim życiu doświadczyli różnych, traumatycznych zdarzeń (odpowiednio: 68,9\% i 41,7\%). Z kolei zdecydowany brak działania, lub jego umiarkowany charakter częściej eksponują respondenci, którzy w swoim życiu nie przeżyli traumatycznych zdarzeń (odpowiednio: 44,4\% oraz 25\%).

Wniosek, jaki można ukonstytuować w związku z powyższym wskazuje, iż respondenci boleśnie doświadczeni przez los potrafią zdecydowanie skuteczniej przeciwdziałać dramatycznym i niebezpiecznym zjawiskom, aniżeli ci, którym takich zdarzeń życie oszczędziło.

Na koniec autorzy opracowania odnieśli się do tzw. wymiarów poznawczych w sytuacji kryzysowej (tab. 9). Badanych studentów poproszono, by przeanalizowali tę kwestię zwracając uwagę na trzy obszary tematyczne (obszar fizyczny - pożywienie, bezpieczeństwo itp., obszar psychiczny - komfort emocjonalny, samoocena itp., obszar moralno-duchowy - poczucie osobistej prawości, wartości moralne, system przekonań itp.) i związane z tym ewentualne zagrożenia.

Tabela 9. Zagrożenia występujące w obszarach (wymiarach poznawczych) dla $\mathrm{n}=85=100 \%$

\begin{tabular}{|c|c|c|c|c|c|c|}
\hline \multirow{3}{*}{$\begin{array}{l}\text { Proszę określić, czy } \\
\text { w wymienionych } \\
\text { obszarach (wymia- } \\
\text { rach poznawczych) } \\
\text { występują jakiekol- } \\
\text { wiek zagrożenia? }\end{array}$} & \multicolumn{6}{|c|}{ Obszary (wymiary poznawcze) } \\
\hline & \multicolumn{2}{|c|}{$\begin{array}{l}\text { Obszar fizyczny } \\
\text { (pożywienie, bezpie- } \\
\text { czeństwo, itp.) dla } \\
\text { n }=85=100 \%\end{array}$} & \multicolumn{2}{|c|}{$\begin{array}{c}\text { Obszar psychiczny } \\
\text { (komfort emocjonalny, } \\
\text { samoocena, itp.) dla } \\
\mathrm{n}=85=100 \%\end{array}$} & \multicolumn{2}{|c|}{\begin{tabular}{|c|} 
Obszar moralno-du- \\
chowy (poczucie osobi- \\
stej prawości, wartości \\
moralne, system \\
przekonań, itp.) dla \\
n $=85=100 \%$
\end{tabular}} \\
\hline & $\mathrm{N}$ & $\%$ & $\mathrm{~N}$ & $\%$ & $\mathrm{n}$ & $\%$ \\
\hline $\begin{array}{l}\text { Zdecydowanie tak, } \\
\text { istnieje taka możli- } \\
\text { wość, że wydarzy się } \\
\text { sytuacja kryzysowa }\end{array}$ & - & - & - & - & - & - \\
\hline $\begin{array}{l}\text { Raczej tak, chociaż } \\
\text { rachunek prawdopo- } \\
\text { dobieństwa wydaje } \\
\text { się niewielki }\end{array}$ & 7 & 8,2 & 12 & 14,1 & 7 & 8,3 \\
\hline Trudno powiedzieć & 16 & 18,8 & 19 & 22,3 & 14 & 16,4 \\
\hline $\begin{array}{l}\text { Raczej nie, chociaż } \\
\text { w życiu niczego nie } \\
\text { można wykluczyć }\end{array}$ & 29 & 34,1 & 34 & 40 & 28 & 32,9 \\
\hline $\begin{array}{l}\text { Nie, nie ma takiej } \\
\text { możliwości w naj- } \\
\text { bliższym czasie }\end{array}$ & 33 & 38,9 & 20 & 23,6 & 36 & 42,4 \\
\hline
\end{tabular}

Źródło: badania własne.

Wyniki dla ogółu badanych respondentów wskazują jednoznacznie, iż dostrzegają oni ewentualne zagrożenia, które mogą być przyczyną kryzysu, niemniej jednak zarówno 
w przypadku obszaru fizycznego - 8,2\%, psychicznego - 14,1\% oraz moralno-duchowego - 8,3\% uzyskane dane są na tyle niewielkie, że nie mogą one przysłonić statystycznego obrazu całości. A tutaj wyraźnie studenci akcentują swoje opinie: i tak w przypadku obszaru fizycznego - 73\% z nich uważa, iż rachunek prawdopodobieństwa wystąpienia jakiegokolwiek zdarzenia kryzysowego jest raczej niewielki, lub nie występuje wcale. Dla blisko 64\% ankietowanych analogiczna sytuacja ma miejsce w przypadku obszaru psychicznego. Największy odsetek stanowią jednak ci badani, którzy nie dostrzegają poważniejszych zagrożeń w obszarze moralno-duchowym (75,3\%). Godne z empirycznego punktu widzenia jest również to, że niemały odsetek respondentów na zadane w ankiecie pytanie nie potrafił odpowiedzieć. Wniosek wydaje się tutaj dość oczywisty, co zresztą przewidywali autorzy niniejszego opracowania, a mianowicie współcześni młodzi ludzie reprezentujący dwie największe, rzeszowskie uczelnie w znaczącej większości optymistycznie patrzą w przyszłość bagatelizując jakiekolwiek zagrożenia czy sytuacje kryzysowe w życiu doczesnym. Tu jednak należy zaznaczyć, iż są wśród nich i tacy, którzy mają w tej kwestii uzasadnione wątpliwości.

\section{WERYFIKACJA HIPOTEZ I WNIOSKI}

Nie sposób w tym stosunkowo krótkim artykule odpowiedzieć na wszystkie, nurtujące autorów pytania. Niemniej jednak sam problem szeroko rozumianej sytuacji kryzysowej został zasygnalizowany i w opinii piszących powinien być kontynuowany. Warto odnotować, iż większość postawionych hipotez znalazła potwierdzenie w badaniach, jeśli nie całkowite to przynajmniej częściowe. I tak hipoteza główna znalazła potwierdzenie w badaniach bowiem niezależnie od tego czy mamy do czynienia z obszarem fizycznym, psychicznym czy moralno-duchowym badani studenci zdecydowanie stoją na stanowisku, iż jakiekolwiek zagrożenia w obecnej rzeczywistości są raczej mało prawdopodobne (odpowiednio: $73 \%, 64 \%$ i $75,3 \%$ ).

Ponadto:

- Płeć badanych wyraźnie różnicuje odpowiedzi respondentów i tak ankietowani studenci częściej wybierają odpowiedź twierdzącą w przypadku trafnego zdefiniowania indywidualnych i zbiorowych środków ratowniczych aniżeli ma to miejsce w przypadku studentek (odpowiednio: $60 \%$ i $30 \%$ ). Z powyższego wynika, że postawiona hipoteza znalazła potwierdzenie w badaniach.

- Miejsce zamieszkania również nie ma istotnego wpływu na rozpoznanie oraz identyfikację a także dotarcie do zbiorowych środków ratunkowych na jednostce pływającej przez badanych, okazało się bowiem, że większość badanych nie potrafi na zadane w ankiecie pytanie odpowiedzieć, z tym, że najmocniej akcentują to respondenci pochodzący ze wsi $(77,1 \%)$, a najsłabiej ci, którzy na stałe zamieszkują w dużych miastach (ponad 38\%).

- Kolejna hipoteza dotycząca przewidywalności zachowania na tratwie ratunkowej w korelacji z typem uczelni, na której studiują respondenci potwierdziła się tylko częściowo, bowiem zarówno studenci Uniwersytetu, jak i Politechniki częściej nie potrafili na zadane w ankiecie pytanie odpowiedzieć (odpowiednio: 78,9\% i 59,2\%) aniżeli udzielić odpowiedzi przeczącej.

- W badaniach znalazła potwierdzanie kolejna hipoteza, bowiem niezależnie od tego, czy ankietowani deklarują się jako wierzący czy niewierzący w ekstremalnej sytuacji 
kryzysowej przykładowo na morzu potrafią podporządkować się dowódcy tratwy ratunkowej (odpowiednio: 53\% i 80\%).

- Proponowany przez autorów badania baton energetyczny niezależnie od deklarowanej aktywności fizycznej studentów spełnił po części swoją rolę - po jego zjedzeniu, większość respondentów czuła częściowe bądź też całkowite uczucie sytości. Z takim stanowiskiem zgodziło się blisko $67 \%$ regularnie uprawiających sport, 57,7\% nieregularnie i 52\% sporadycznie. Nie zgodziło się z tym 42,9\% tych, którzy nie podejmują żadnej aktywności fizycznej.

- W przypadku kolejnej hipotezy mamy do czynienia z jej potwierdzeniem, bowiem ci respondenci, którzy potrafią pływać zdecydowanie lepiej radzą sobie ze strachem czy lękiem w sytuacji kryzysowej od tych, którzy z pływaniem są na bakier (odpowiednio: $69,6 \%$ i $31 \%$ )

- Ostatnia z hipotez znalazła tylko częściowe potwierdzanie w badaniach, bowiem zdecydowane lub częściowe działanie deklarują przede wszystkim ci respondenci, którzy w swoim życiu doświadczyli traumatycznych przeżyć $(68,9 \%)$. Z kolei ci, których to ominęło stanowią niecałe $42 \%$ badanych.

\section{PRAWODAWSTWO}

1. Zmiany do załącznika do Międzynarodowej konwencji o bezpieczeństwie życia na morzu, 1974, sporządzonej w Londynie dnia 1 listopada 1974 r., zmienionej Protokołem sporządzonym w Londynie dnia 17 lutego 1978 r. oraz Protokołem przyjętym w Londynie dnia 11 listopada 1988 r., przyjęte w Londynie dnia 22 maja 2014 r. i dnia 21 listopada 2014 r. (Dz.U. z 2016 r. poz. 2029).

2. Międzynarodowa konwencja o bezpieczeństwie życia na morzu, 1974 r., sporządzona w Londynie dnia 1 listopada 1974 r., zmieniona Protokołem sporządzonym w Londynie dnia 17 lutego 1978 r. oraz Protokołem przyjętym w Londynie dnia 11 listopada 1988 r. (Dz.U. z 2016 r., poz. 869).

\section{NETOGRAFIA}

1. https://pl.wikipedia.org/wiki/Plutarch

2. https://pl.wikipedia.org/wiki/Guglielmo_Marconi

3. https://pl.wikipedia.org/wiki/Kod_Morse\%E2\%80\%99a

4. http://www.polskieradio.pl/39/156/Artykul/861474,Juz-ponad-wiek-nadajemy-sygnal-SOS

5. https://pl.wikipedia.org/wiki/CQD

6. https://prawomorza.pl/ujednolicone-teksty-konwencji-solas-i-marpol-w-dzienniku-ustaw/

7. http://ratownictwo.am.szczecin.pl/index.php/dla-studentow/ratownictwo-morskie/31-kodeks-lsa

8. http://www.sealight.pl/

\section{ATTITUDES OF A MODERN ACADEMIC YOUTH AT THE CRISIS SITUATION (WITH THE USE OF RESCUE EQUIPMENT)}

This article is an attempt to approximate the dangers of maritime shipping. However, due to the multiform and diversity of issues that describe human security and also due to volume of 
the article, the authors consciously gave up the description of many issues and problems surrounding this topic.

A difficult situation usually occurs unexpectedly and requires a change of perspective in a short time. This change affects self-esteem. One gets rid of hope and illusions and then feels mental and physical exhaustion. In a crisis situation occurring at sea, when a person's life and health are at risk actions are being undertaken to minimize the effects of threats.

On all passenger ships demonstrations are being performed by the crew and volunteers among passengers. In accordance with the STCW (International Convention on Standards of Training, Certification and Watchkeeping for Seafarers) seamen should undergo the training of the operation of rescue measures.

The first part presents basic legal acts dealing with the investigated problem with particular emphasis on the equipment of rescue vessels.

The next part of the article doesn't focus on the destructive situation. A topic of this study is not a description of a sea catastrophe, but the behavior of people, including the search for a leader among the survivors, without a full-time commander.

The innovation of the article is the application of "food rations" that are provided by the life raft in humanitarian disasters among respondents and their evaluation.

Keywords: catastrophe, castaway, lifeguard, life raft, behavior.

DOI: 10.7862/rz.2018.hss.31

Przestano do redakcji: grudzień $2017 \mathrm{r}$.

Przyjęto do druku: czerwiec 2018 r. 
